\title{
Primates and protected areas in Suriname
}

\author{
Ferdinand L. J. Baal, Russell A. Mittermeier and Marc G. M. van Roosmalen
}

\begin{abstract}
Suriname is a small country, but it still has large tracts of undisturbed forests and rich wildlife. The authors discuss Suriname's plans to extend its already excellent network of protected areas and proposals to amend the hunting regulations. They also consider the country's eight monkey species, whose status can be regarded as indicative of that of the rest of the country's wildlife.
\end{abstract}

Suriname, one of the smallest countries in South America, obtained its independence from the Netherlands in 1975. With a human population of only 377,000 in an area of $163,265 \mathrm{sq} \mathrm{km}$, it is one of the least densely populated tropical countries in the world, and 95 per cent of this population is concentrated in the capital city, Paramaribo, and in several other smaller towns in the coastal region. Only about 5 per cent of the population lives in the interior, mostly in scattered villages along three major rivers (Figure 1). Otherwise, the interior is uninhabited and covered with undisturbed Neotropical forest, making Suriname one of the best places for conservation of this biome (Schulz et al., 1977).

Suriname has an excellent protected area network, but plans are under way to expand it still further, more than doubling the number of reserves and quadrupling the area under protection. This article gives some background to the current situation in Suriname, discusses existing wildlife conservation measures, particularly plans for expansion of the protected area network, and finally focuses on one group of animals, the nonhuman primates, which are an excellent indicator for the status of all wildlife in the country.

\section{The land}

Lying between $2-6^{\circ} \mathrm{N}$ and $54-56^{\circ} \mathrm{W}$, Suriname has a typical tropical climate with a mean daily temperature of about $27^{\circ} \mathrm{C}$ and an annual range of only $2^{\circ} \mathrm{C}$. Annual rainfall varies between 2000 Primates and protected areas in Suriname and $2500 \mathrm{~mm}$, and humidity is generally high. There are two rainy seasons, a major one lasting approximately from May to July and a minor one from December to January, and two dry seasons, a major one from August to November and a minor one from February to April.

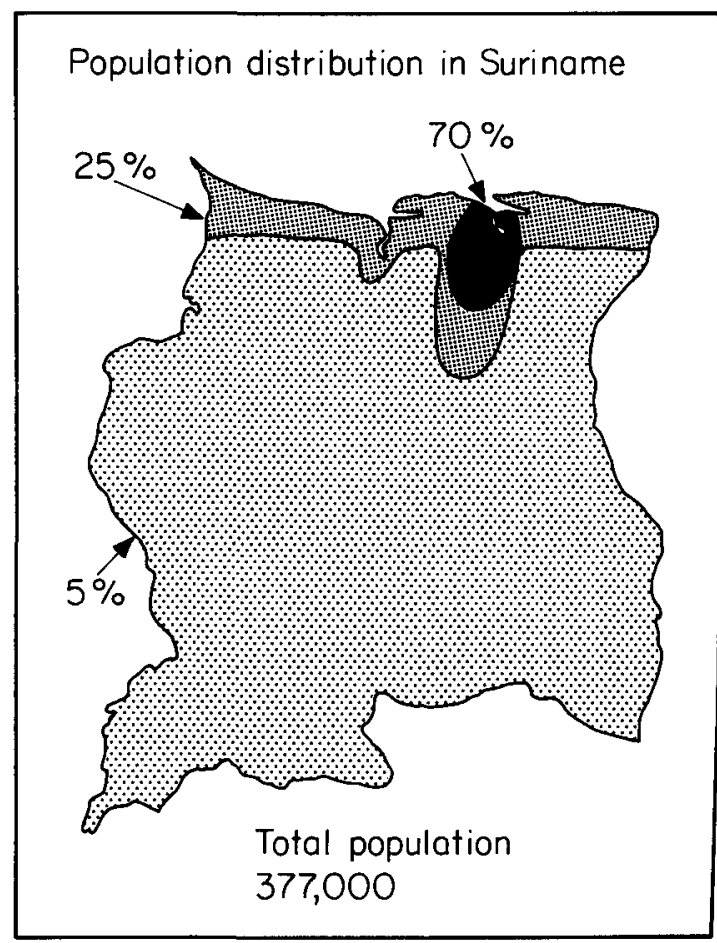

Figure 1. Distribution of Suriname's human population. Note that the vast interior is largely uninhabited. 
Geomorphological characteristics, rather than climate, are responsible for Suriname's diversity of forest types and ecological zones, with the following being the broadly defined zones of the country (Figure 2).

(1) Young coastal plain: consists mainly of coastal swamps at or below high-tide level. Natural vegetation consists of mangrove forests, open herbaceous swamps and several types of swamp forest.

(2) Old coastal plain: situated 4-11 m above sea level. Natural vegetation consists of rain forests, marsh forest and swamp vegetation

(3) Zanderij formation: situated 10-70 m above sea level and consists mainly of sandy deposits. Natural vegetation is composed mainly of open and shrub savanna interspersed with savanna forests and high rain forests on unbleached moist soil.

(4) The interior: covers three-quarters of the country and consists mainly of rugged, rolling terrain on the ancient Guayana Shield, Natural vegetation is primarily evergreen rain forest interspersed with savannas, and savanna forests along ridges and swamps, and swamp forests along creeks and stream valleys.

\section{Wildlife conservation and protected areas}

Suriname's diverse fauna includes at least 674 species of birds, 200 species of mammals, 130 species of reptiles, 99 species of amphibians, more than 300 freshwater fish, and at least 50 species of brackish-water fish. The wildlife is protected both by the nature reserve system and by hunting laws. The categories of protected areas are:

(a) Nature Reserves. In 1954, the Nature Conservation Law provided for the establishment of nature reserves by government resolution, and made public lands eligible for reserve status if they were considered to be of scientific, aesthetic or cultural value. Management of nature reserves is in the hands of the Suriname Forest Service. The nature reserves include representative samples of most of the country's major landscapes and ecosystems, all of them uninhabited, and all land within the boundaries of nature reserves is in the 8

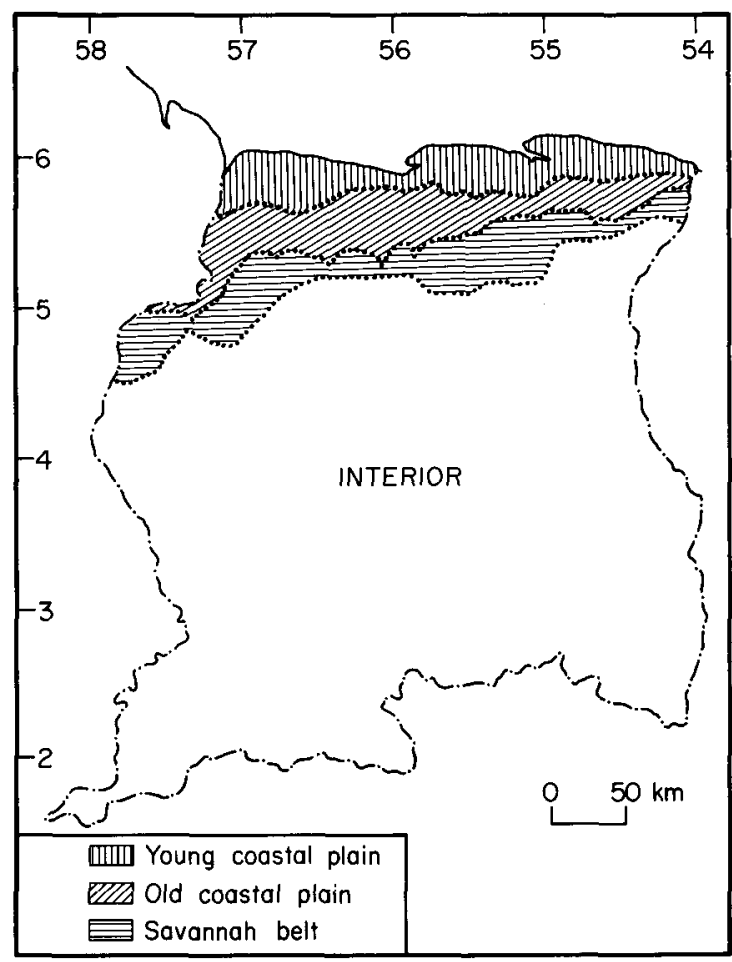

Figure 2. The major zones of Suriname.

hands of the Government. There are nine nature reserves (Figure 3 ), and there are plans to increase the number to 15 .

(b) Special protection forests or forest reserves. Forest exploitation is prohibited in these areas.

(c) Special management areas. Some forms of exploitation, for example agriculture, animal husbandry or fisheries, are allowed under certain management conditions.

(d) Concessions and long-term lease areas. It is possible to establish nature parks in this category, well-known examples being Brownsberg Nature Park of the Foundation for Nature Preservation in Suriname (Stichting Natuurbehoud Suriname STINASU).

Table 1 summarizes the areas covered by present and proposed protected areas in Suriname, while Figure 3 shows the locations of present and proposed nature reserves.

Wildlife management is regulated by the Game

Oryx Vol 22 No 1, January 1988 
Law of 1954 and the Game Resolution of 1970 , while the Forest Service is responsible for the implementation of these on behalf of the Ministry of Agriculture, Animal Husbandry, Fisheries and Forestry. The most important article of the Game Law is Article 1, which dictates that all mammals, birds, sea turtles and other indicated species are totally protected, except those designated in the Game Resolution as game, pet or harmful species. Game species may be hunted, transported, sold, exported and so forth only during the respective open hunting seasons, while harmful species may be killed, captured, exported and so on without licence throughout the year. Article 15 prohibits the import and transit of wild animals and/or their products if they are illegally caught or transported in, or illegally exported from, the country of origin.

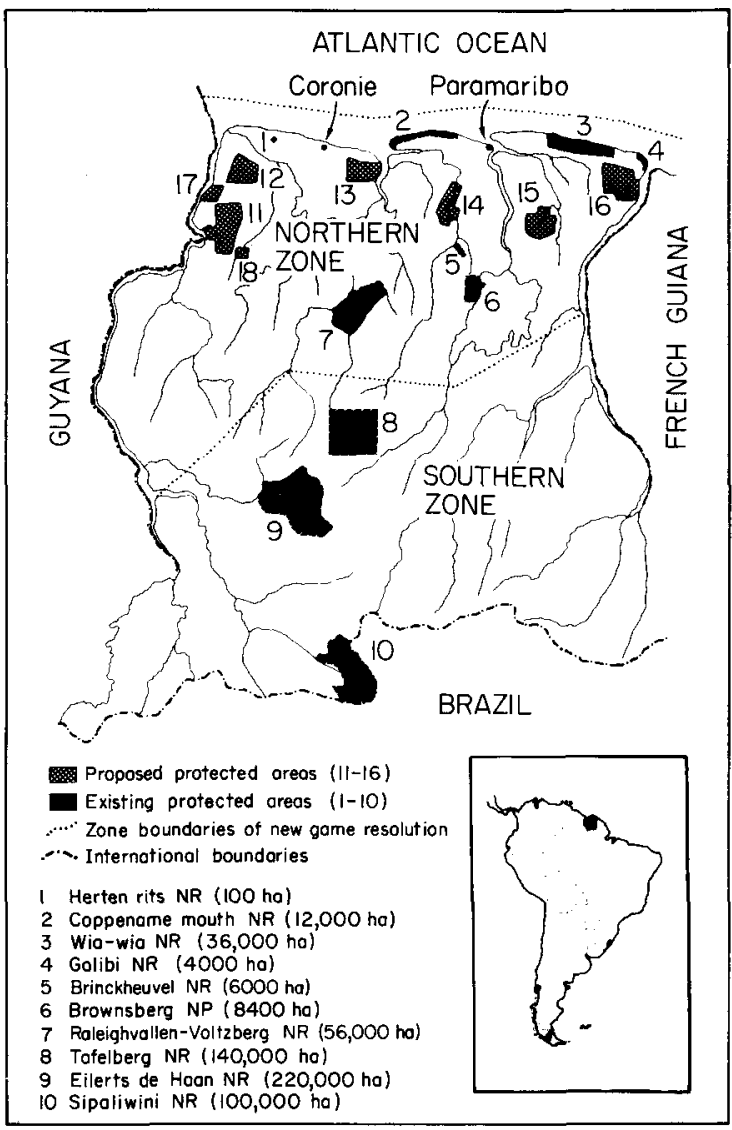

Figure 3. Existing protected areas in Suriname $(1-10)$, together with the new protected areas that have been proposed $(11-18)$.
The most important amendments to the present Law (1954) and Resolution (1970) are, or will be, as follows.

(a) A new category of pet species will be established to replace the category of 'domesticated' species.

(b) Bag limits for some game and pet species will be introduced.

(c) The use of nets and artificial light will be allowed only under certain conditions. Prohibited weapons are mentioned in the Resolution.

(d) It will be possible in the future to require from the hunter a medical certificate and a test (concerning, for example, fauna, habitat and safety) before issuing a hunting licence.

(e) Separate rules may be established by Resolution for import, transit and export of game species, pets, or their products.

(f) Ranched or farmed animals will, under certain conditions, be exempted from the rules concerning closed seasons, import, export and so on.

(g) Customs are in charge of controlling import, transit and export of wild fauna.

(h) The game wardens will have the authority to write a ticket for straightforward transgressions of the Game Law.

(i) Under exceptional conditions the Minister of Agriculture, Animal Husbandry, Fisheries and Forestry may change the hunting season, the bag limit, and the means of hunting for game, pet and harmful species in a calendar year.

(j) The 200-mile economic zone, which is about the same size as the land surface, will be covered by the Game Law, thus protecting marine species.

(k) The rules concerning hunting seasons and bag limits for game and pet species will not apply for the Southern Zone (Figure 3), where the people are subsistence hunters.

\section{Conservation of primates}

Eight species of Neotropical primates representing seven genera and two families are found in Suriname. None of these appears to be endangered at present. All have large healthy populations in the uninhabited interior, and they 
receive full protection in the nature reserves and nature park. In contrast to most other parts of the world, habitat destruction is still a relatively minor factor and, although parts of the coastal region have been affected by agriculture and mining, the primates in these areas are adaptable, and as long as some forest habitat remains they continue to do well. In the interior, slash-and-burn agriculture takes place only in the vicinity of villages. Its effect is minimal, and the habitat mosaic it creates is almost certainly beneficial to some primate species adapted to the forest edge, for example the golden-handed tamarin*. There has been some forest clearance for charcoal production and to make way for plantations of exotics (Caribbean pine for example), but this has been on a small scale.

The most damaging habitat destruction that has occurred so far has been the damming of the Suriname River for hydroelectric power. This project, which was completed in 1964, resulted in the flooding of $2250 \mathrm{sq} \mathrm{km}$ of rain forest in the north-eastern part of the country and the destruction of a large tract of primate habitat. A similar project has been planned for several years for the Kabalebo River area in western Suriname, but the dam will not be built in the course of this decade.

At present primate hunting is probably more of a threat than is habitat destruction, at least as far as the larger species are concerned. Even so, the effects of hunting vary considerably from area to area, depending on local traditions, tastes and taboos, and on the availability of other sources of protein (Mittermeier, 1977).

The 1954 Game Law and the 1970 Game Resolution provide official protection for all primates except the brown or tufted capuchin, which is listed as a game species. New legislation is proposed that will bring the two small monkeys, the golden-handed tamarin and the squirrel monkey, into the pet species category. The other, larger, primates will become game species, but with a closed season lasting the whole year in the Northern Zone, which means that the six larger species will be fully protected there. In the

* Scientific and other names of species are given in Appendix 1.
Southern Zone, where only a small number of subsistence hunters live, the hunting season for primates will be open all year.

Enforcement of legislation is quite good, and better organized than in most other parts of South America. Live capture of primates for export has never been allowed in Suriname, except for scientific purposes. Live capture to serve a local market does occur, but on a small scale. In a 15-month period extending from April 1975 to February 1977 only 84 primates were seen being kept as pets, and most of these were in the interior. The capture of infants for pets is usually an incidental effect of meat hunting. If a hunter sees a female with an infant, he often shoots at her in preference to other group members. Although the infant is sometimes killed by the fall or by stray shot, if it survives the hunter gains a pet, which he can either keep or sell in town.

A number of early investigations on the primates of Suriname have been published. Thanks to STINASU, the Nature Conservation Division of the Forest Service and the facilities they have provided, a considerable amount of recent research has also been conducted, most of it in

Table 1. Present and proposed protected areas

$$
\begin{array}{ll}
\begin{array}{l}
\text { Area Per cent } \\
(\mathrm{sq} \mathrm{km})
\end{array} & \begin{array}{l}
\text { of land } \\
\text { surface }
\end{array}
\end{array}
$$

\section{Established up to 1983}

Nine nature reserves

One nature park (Brownsberg)

Sub-total

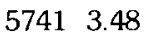

840.05

$5825 \quad 3.53$

\section{Proposed up to 1983}

Enlargement of Raleighfalls Nature Reserve $\quad 196 \quad 0.12$

Enlargement of Brownsberg Nature Park $\quad 100 \quad 0.06$

Six nature reserves

Four forest reserves

26301.59

Two special management areas:

- entire estuarine zone

2120.13

-Kabalebo area

$3100 \quad 1.89$

Sub-total

Total established and proposed up to

1983

Fifteen nature reserves

One nature park

Four forest reserves

Two special management areas

Total
85675.19

1840.11

$212 \quad 0.13$

$14,600 \quad 8.85$

$23,56314.28$ 
the second half of the 1970s (for example, 1981; Mittermeier and van Roosmalen, 1981, Mittermeier, 1977, 1978; Buchanan, 1978; 1982; van Roosmalen, 1980; van Roosmalen et Fleagle and Mittermeier, 1980; Buchanan et al., al., 1981).

Table 2. Conservation status of Suriname primates

\begin{tabular}{|c|c|c|c|c|c|c|c|c|}
\hline & $\begin{array}{l}\text { Saguinus } \\
\text { midas } \\
\text { midas }\end{array}$ & $\begin{array}{l}\text { Saimiri } \\
\text { sciureus } \\
\text { sciureus }\end{array}$ & $\begin{array}{l}\text { Pithecia } \\
\text { pithecia }\end{array}$ & $\begin{array}{l}\text { Chiropotes } \\
\text { satanas } \\
\text { chiropotes }\end{array}$ & $\begin{array}{l}\text { Cebus apella } \\
\text { apella }\end{array}$ & $\begin{array}{l}\text { Cebus } \\
\text { nigrivittatus }\end{array}$ & $\begin{array}{l}\text { Aloutta } \\
\text { seniculus }\end{array}$ & $\begin{array}{l}\text { Ateles } \\
\text { paniscus } \\
\text { paniscus }\end{array}$ \\
\hline Abundance & Common & Common & Rare & Rare & Common & Rare & Common & $\begin{array}{l}\text { Locally } \\
\text { common in } \\
\text { high forest }\end{array}$ \\
\hline Range & $\begin{array}{l}\text { Interior and } \\
\text { old coastal } \\
\text { plain }\end{array}$ & $\begin{array}{l}\text { Entire } \\
\text { country }\end{array}$ & $\begin{array}{l}\text { Entire } \\
\text { country }\end{array}$ & Interior & $\begin{array}{l}\text { Entire } \\
\text { country }\end{array}$ & Interior & $\begin{array}{l}\text { Entire } \\
\text { country }\end{array}$ & Interior \\
\hline Niche breadth* & "High & High & Low & Low & High & Low & Low & Low \\
\hline $\begin{array}{l}\text { Reaction to } \\
\text { man-induced } \\
\text { habitat } \\
\text { disturbances }\end{array}$ & $\begin{array}{l}\text { Adaptable; } \\
\text { may benefit } \\
\text { from } \\
\text { certain kinds }\end{array}$ & $\begin{array}{l}\text { Adaptable; } \\
\text { may benefit } \\
\text { from } \\
\text { certain kinds }\end{array}$ & $?$ & $\begin{array}{l}\text { Disappears } \\
\text { in the face } \\
\text { of habitat } \\
\text { alteration }\end{array}$ & $\begin{array}{l}\text { Adaptable; } \\
\text { may benefit } \\
\text { from certain } \\
\text { kinds }\end{array}$ & ? & $\begin{array}{l}\text { Usually } \\
\text { disappears } \\
\text { but more } \\
\text { adaptable } \\
\text { than Ateles } \\
\text { or Chiropotes }\end{array}$ & $\begin{array}{l}\text { Disappears } \\
\text { in the face } \\
\text { of habitat } \\
\text { alteration }\end{array}$ \\
\hline $\begin{array}{l}\text { Importance } \\
\text { as a food } \\
\text { item }\end{array}$ & $\begin{array}{l}\text { Rarely } \\
\text { eaten }\end{array}$ & $\begin{array}{l}\text { Rarely } \\
\text { eaten }\end{array}$ & $\begin{array}{l}\text { A preferred } \\
\text { species, } \\
\text { but rarely } \\
\text { shot }\end{array}$ & Important & Important & $\begin{array}{l}\text { A preferred } \\
\text { species, } \\
\text { but rarely } \\
\text { shot }\end{array}$ & Important & Important \\
\hline $\begin{array}{l}\text { Vulnerability } \\
\text { to hunting }\end{array}$ & $\begin{array}{l}\text { Relatively } \\
\text { easy to } \\
\text { shoot but } \\
\text { rarely } \\
\text { hunted }\end{array}$ & $\begin{array}{l}\text { Very easy } \\
\text { to shoot } \\
\text { but rarely } \\
\text { hunted }\end{array}$ & $\begin{array}{l}\text { Very } \\
\text { difficult } \\
\text { to shoot }\end{array}$ & $\begin{array}{l}\text { Relatively } \\
\text { easy to } \\
\text { shoot }\end{array}$ & $\begin{array}{l}\text { Relatively } \\
\text { easy to } \\
\text { shoot }\end{array}$ & $\begin{array}{l}\text { Difficult } \\
\text { to shoot }\end{array}$ & $\begin{array}{l}\text { Relatively } \\
\text { easy to } \\
\text { shoot }\end{array}$ & $\begin{array}{l}\text { Very easy } \\
\text { to shoot }\end{array}$ \\
\hline $\begin{array}{l}\text { Reproductive } \\
\text { rate }\end{array}$ & $\begin{array}{l}\text { At least } \\
\text { two infants } \\
\text { per year }\end{array}$ & $\begin{array}{l}\text { One } \\
\text { infant } \\
\text { per year }\end{array}$ & ? & $\begin{array}{l}\text { Probably } \\
\text { one infant } \\
\text { per year }\end{array}$ & $\begin{array}{l}\text { One infant } \\
\text { per year }\end{array}$ & $\begin{array}{l}\text { Probably } \\
\text { one infant } \\
\text { per year }\end{array}$ & $?$ & $\begin{array}{l}\text { One infant } \\
\text { every three } \\
\text { to four years }\end{array}$ \\
\hline $\begin{array}{l}\text { Conservation } \\
\text { status }\end{array}$ & A & A & $\mathrm{C}$ & $\mathrm{D}$ & B & C & B & $\mathrm{D}$ \\
\hline $\begin{array}{l}\text { Game } \\
\text { Resolution } \\
1970\end{array}$ & Protected & Protected & Protected & Protected & Game & Protected & Protected & Protected \\
\hline $\begin{array}{l}\text { Concept } \\
\text { New Game } \\
\text { Resolution }\end{array}$ & Pet & Pet & Game $\dagger$ & Gamet & Gamet & Game ${ }^{\dagger}$ & Game ${ }^{\dagger}$ & Gamet \\
\hline
\end{tabular}

Key: (A) not in any danger, widespread, abundant, adaptable, little persecuted;

(B) in little danger, widespread, abundant, adaptable, but subject to considerable hunting pressure and may be harmed by heavy exploitation;

(C) somewhat vulnerable, rare species that are only moderately adaptable and subject to considerable hunting pressure;

(D) vulnerable, little or no adaptability to human intrusion, and subject to considerable hunting pressure.

*Based on relative utilization of different forest types (calculations in Mittermeier, 1977).

tDuring the whole year, hunting is closed in the Northern Zone but open in the Southern Zone.

Primates and protected areas in Suriname 
The conservation status of the eight non-human primates found in Suriname is given in Table 2, while Appendix 1 summarizes the characteristics of these species.

The golden-handed tamarin and the squirrel monkey are undoubtedly the least threatened, while those in most danger are the bearded saki and the black spider monkey. Only the latter is considered sufficiently threatened to warrant a place in the IUCN Red Data Book, and this is mainly because of its declining status in other parts of its range.

All the Suriname monkeys are well represented in protected areas, and plans are under way to establish six new nature reserves and four forest reserves, as well as to expand some of those already in existence. Efforts are also being made to establish a Research Station at Raleighvallen-

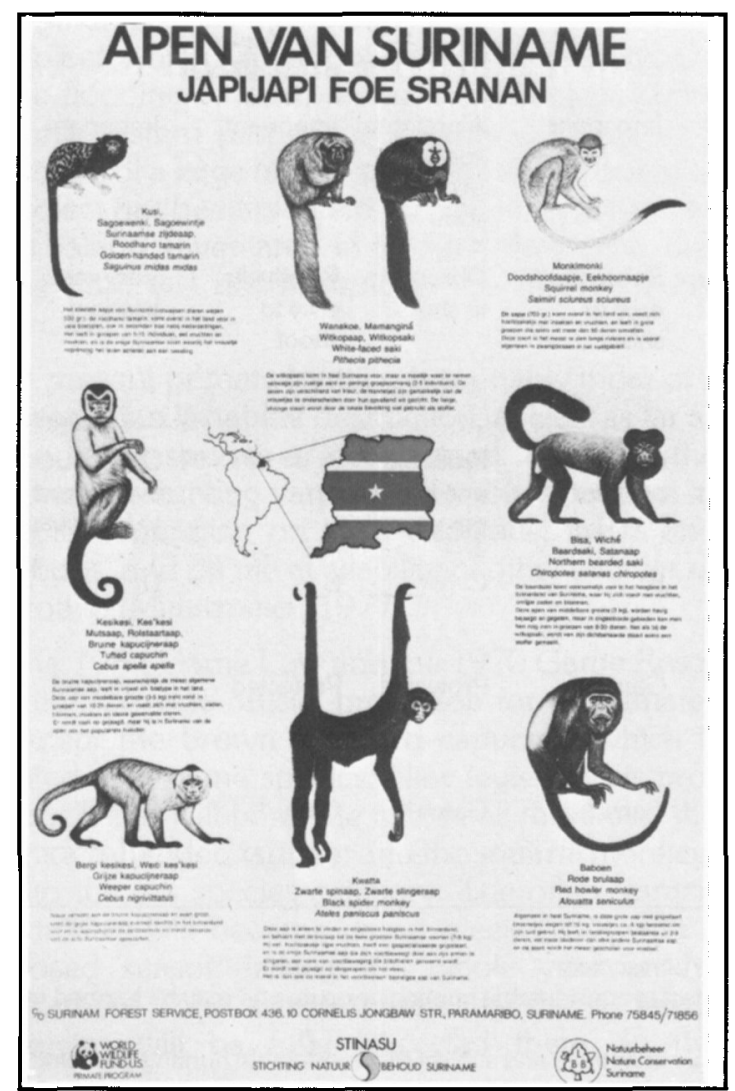

Poster depicting the eight Suriname monkey species, produced by the WWF for STINASU and the Suriname Forest Service.

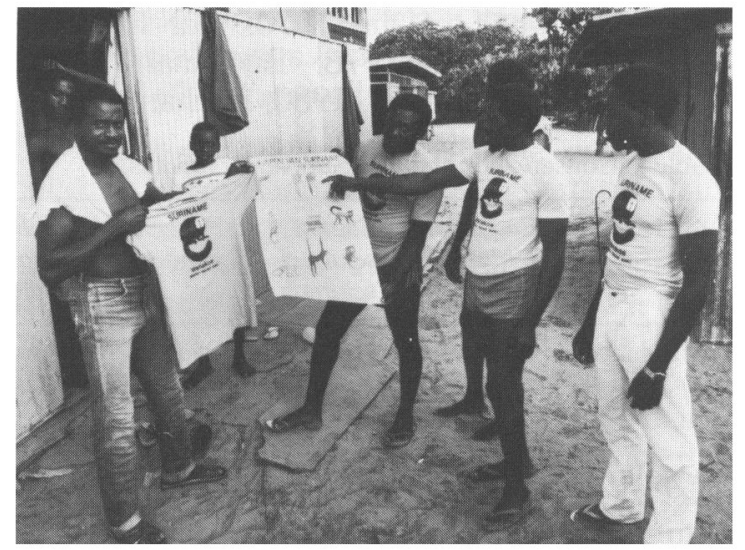

Guards at one of Suriname's reserves admiring new posters and $T$-shirts.

Voltzberg Nature Reserve for the study of the flora and fauna of the tropical rain forest. Research on primates will be continued at this station. However, international funds are necessary to implement this plan.

As things now stand, Suriname is one of the best places for tropical forest and wildlife conservation in all of South America, and is a major stronghold for the eight monkey species and other Neotropical animals that occur within its borders. Fortunately, it is likely to remain so for many years to come.

Appendix 1. Summary of characteristics of the eight primates in Suriname (note: order of names: English, Suriname, Dutch and scientific).

Golden-handed tamarin; kusi, saguwenki; Surinaamse zijdeaap; Saguinus midas midas.

Smallest of the Suriname monkeys (adult weight $500 \mathrm{~g}$ ), the golden-handed tamarin is found in many forest types, including secondary forest near human habitation. It lives in groups of 5-15 individuals, eats fruits and insects, and is the only Suriname species that regularly gives birth to twins.

Squirrel monkey; Monkimonki; Doodskopaap, Eekhoornaap; Saimiri sciureus sciureus.

This small monkey $(700 \mathrm{~g})$ occurs throughout the country, feeds mainly on insects and fruits, and lives in large groups, which may consist of more than 50 animals. It is the species most often seen Oryx Vol 22 No 1, January 1988 


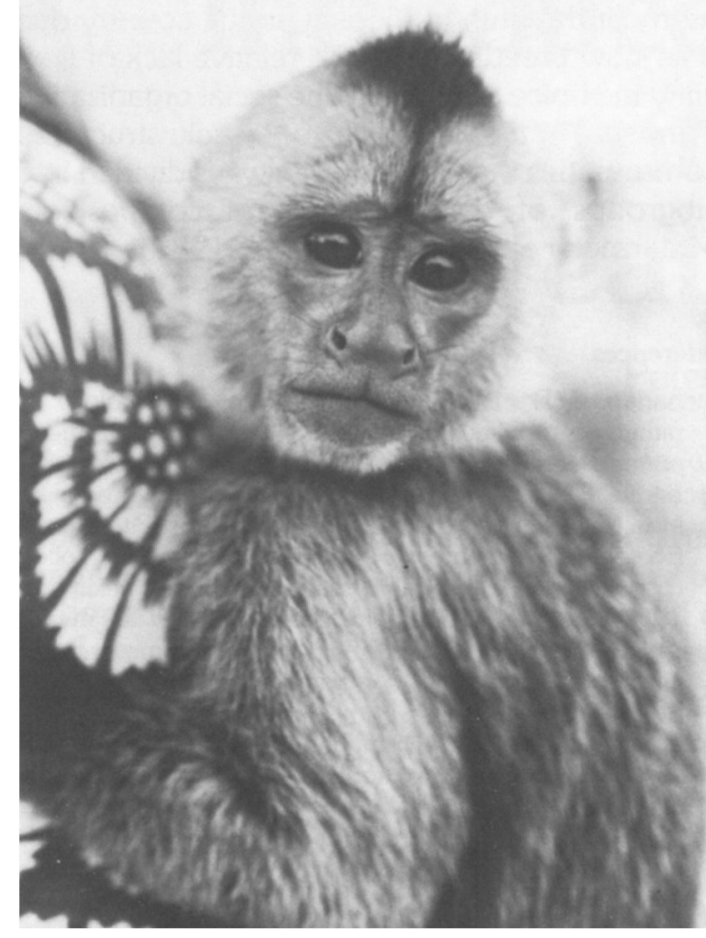

Weeper capuchin, rarest of Suriname's monkeys (R.A. Mittermeier).

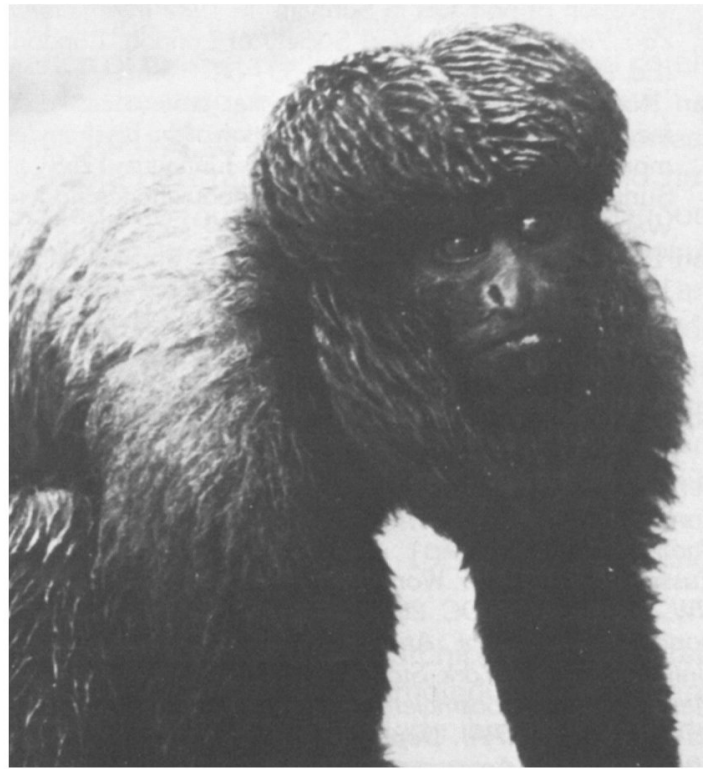

Bearded saki, restricted mainly to the interior of Suriname (R.A. Mittemeier).

Primates and protected areas in Suriname

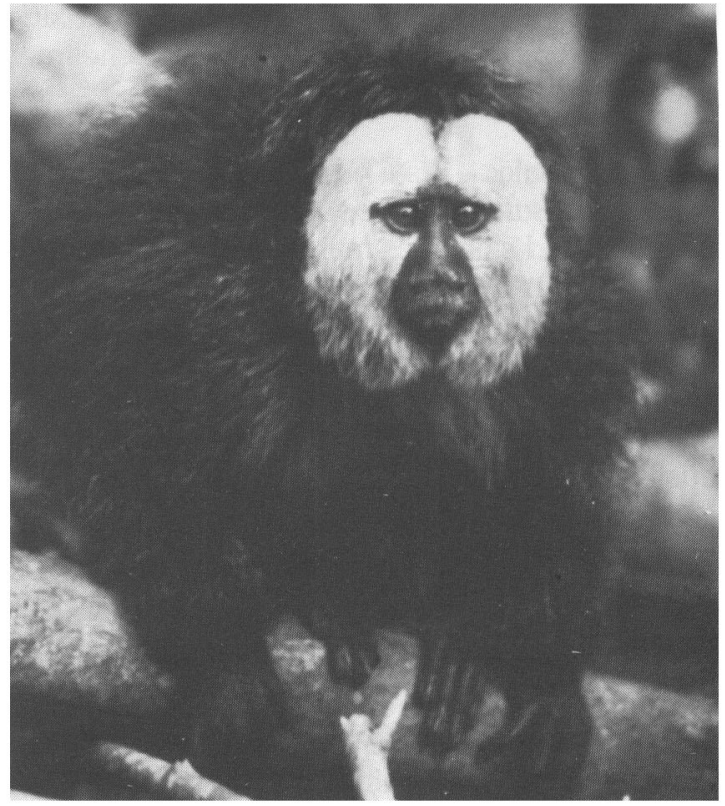

Male white-faced saki (R.A. Mittermeier).

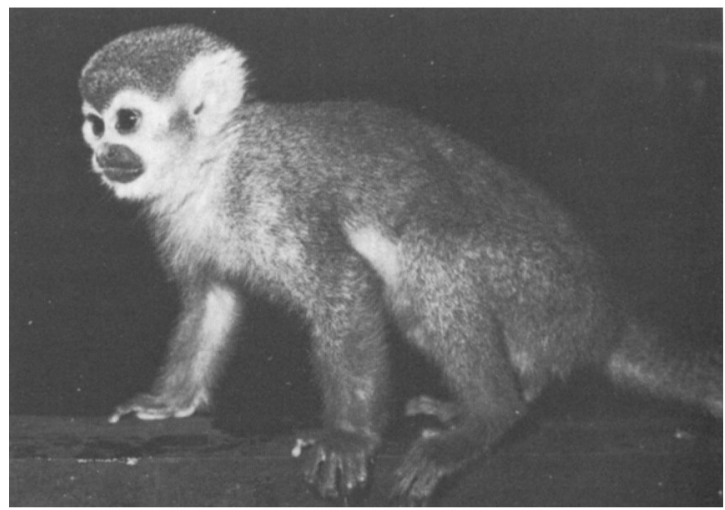

Squirrel monkey, smallest of Suriname's cebid monkeys and very common in the coastal swamp forests (R.A. Mittermeier).

along rivers, and is especially common in swamp forests of the coastal region.

White-faced saki; wanaku, mamanginá; witkopaap, witkopsaki; Pithecia pithecia.

The white-faced saki $(1.5-2.5 \mathrm{~kg})$ occurs throughout Suriname, but is difficult to see because of its quiet habits and small group size (2-5 individuals). The species is sexually dimorphic in colour, and males can easily be 
distinguished from females by their striking white faces. The long, fluffy tail is sometimes used as a duster by the local people

Bearded saki; Bisa; Baardsaki, Satanaap; Chiropotes satanas chiropotes.

The bearded saki lives mainly in the high forests of the interior of Suriname where it feeds on fruit, unripe seeds and flowers. These medium sized monkeys $(3 \mathrm{~kg})$ are heavily hunted for food, but in undisturbed areas can still be found in groups of 8-30 animals. Like the white-faced saki, its bushy tail is sometimes turned into a duster.

Brown or tufted capuchin; Kesikesi; Mutsaap, Bruine capucijneraap; Cebus apella apella.

Probably the most common of all the Suriname monkeys, the tufted capuchin lives in almost every forest type in the country. A medium sized monkey $(3-5 \mathrm{~kg})$, it travels in groups of $10-25$ animals feeding on fruits, flowers, seeds, leaves, insects and small vertebrates. It is frequently hunted for food and is also the most popular pet monkey in Suriname.

Weeper capuchin; bergi kesikesi, weiti keskesi; grijze capucijneraap; Cebus nigrivittatus.

This close relative of the tufted capuchin is similar in size but is found only in the mountainous interior, and is probably the rarest and least known of the eight Suriname monkey species.

Red howler monkey; Babun; Rode brulaap; Aloutta seniculus.

Common throughout Suriname, this large, prehensile-tailed monkey (males weigh up to $10 \mathrm{~kg}$, females about $6 \mathrm{~kg}$ ) is famous for its loud roars. It lives in family groups of 2-8 animals, eats more leaves than any other Suriname monkey, and is the species most frequently shot for food.

Black spider monkey; kwatta; Zwarte spinaap, Zwarte slingeraap; Ateles paniscus paniscus.

This monkey lives only in undisturbed high forest in the interior, and is one of the two largest Suriname species $(7-9 \mathrm{~kg})$. It feeds mainly on ripe fruit, has a specialized prehensile tail, and is the only Suriname monkey that moves by an arm-swinging form of locomotion known as brachiation. It is frequently hunted for food and is the most threatened monkey in the country due to its slow breeding rate and relative lack of flexibility in choice of habitat. The social organization is unusual in that it consists of loosely structured "communities that are almost always divided into subgroups of varying size and composition' (Mittermeier and van Roosmalen, 1982).

\section{References}

Buchanan, D.B. 1978. Communication and ecology of pithecine monkeys, with special reference to Pithecia pithecia. Doctoral dissertation. Wayne State University.

Buchanan, D.B., Mittermeier, R.A. and van Roosmalen, M.G.M. 1981. The saki monkeys, genus Pithecia. In Ecology and Behavior of Neotropical Primates, Vol. 1. (Eds A.F. Coimbra-Filho and R.A. Mittermeier, pp. 391-417. Brazilian Academy of Sciences, Rio de Janerio.

Fleagle, J.G. and Mittermeier, R.A. 1980. Locomotor behavior, body size and comparative ecology of seven Surinam monkeys. Am.J.Phy. Anthrop. 52, 301-314.

Mittermeier, R.A. 1977. Distribution, synecology and conservation of Surinam monkeys. Doctoral dissertation. Harvard University.

Mittermeier, R.A. 1978. Locomotion and posture in Ateles geoffroyi and Ateles paniscus. Folia primatol. 30, $161-193$.

Mittermeier, R.A. and van Roosmalen, M.G.M. 1981. Preliminary observations on habitat utilization and diet in eight Surinam monkeys. Folia primatol. 36, 1 - 39.

Mittermeier, R.A. and van Roosmalen, M.G.M. 1982. Conservation of primates in Surinam. In 1982 International Zoo Yearbook Zoological Society of London, London. (Ed. P.J.S. Olney), Vol. 22, pp. 59-68.

van Roosmalen, M.G.M. 1980. Habitat preferences, diet, feeding strategy and social organization of the black spider monkey (Ateles paniscus paniscus Linnaeus 1758) in Surinam. Doctoral dissertation. Landbouwhogeschool te Wageningen, The Netherlands.

van Roosmalen, M.G.M., Mittermeier, R.A. and Milton, K. 1981. The bearded sakis, genus Chiropotes. In Ecology and Behavior of Neotropical Primates, Vol. 1. (Eds A.F. Coimbra-Filho and R.A. Mittermeier), pp. 419-441. Brazilian Academy of Sciences, Rio de Janeiro.

Schulz, J.P., Mittermeier, R.A. and Reichart, H. 1977. Wildlife in Surinam. Oryx, 14, 133-144.

Ferdinand L.J. Baal, Nature Conservation Division, Suriname Forest Service, Postbox 436, 10 Comelis Jongbawstraat, Paramaribo, Suriname.

Russell A. Mittermeier, World Wildlife Fund, 125024 th Street, NW, Washington, DC 20037, USA. (Address for correspondence: Dept of Anatomical Sciences, HSC, State University of New York, Stony Brook, NY 11794,USA.

Marc G.M. van Roosmalen, Instituto Nacional de Pesquisas da Amazonia (INPA), Dept de Botanica, Caixa Postal 478, 69.000 Manaus, Amazonas, Brazil. 